\title{
Communication in Foreign Trade: A Broader Concept for Business Communication in China
}

\author{
Baolin Zong \\ The University of International Business and Economics \\ Herbert W. Hildebrandt \\ University of Michigan
}

A walk through Tiananmen Square in Beijing or a visit to the Beijing University of International Business and Economics suggests visually and intellectually that changes, sometimes dramatic, are taking place in all areas of China's national economy. Such changes are a part of Deng Xiaping's plan for a modern China. As these economic changes occur, the bankers, the accounting firms, the businesspeople-even the many scholars-are increasing their travel between mainland China and Hong Kong, between Beijing, Shanghai, and the foreign capitals of the world.

Obviously, China needs a new generation of better trained businesspeople to cope with the great variety of foreigners intending to do business - every kind of business, from marketing Scotch magic transparent tape to bargaining for a supply of tungsten, from a joint venture project to a possible investment in China's ambitious tourist program.

One of the leading business schools in China-The University of International Business and Economics (UIBE), formerly the Beijing Institute of Foreign Tradeseeks to prepare people for a career in international business. In short, students from UIBE assume leading managerial roles in China's business and often go on to Chinese embassies as commercial counselors.

Thus, central to Chinese students studying functional courses such as finance, accounting, business law, computer and information systems is the vehicle of business communication. In other words, business communication for the Chinese focuses heavily on international communication.

Our purpose is to offer a progress report on a project entitled "Communication in Foreign Trade," suggesting a wider scope to the traditional view of business communication held in the United States.

\section{BACKGROUND}

Currently, UIBE uses in their business communication courses a small two-volume text entitled Business Correspondence. ${ }^{1}$ A charitable statement is that the work has been around, basically unchanged, in China for nearly
30 years. Its examples are outdated; its language is excessively flowery; its main means of communication training is via the mails, via rail and boat, far distant from the modernities of telexes, electronic mail, and increasing use of air transport. Hence the first reason for updating international business communication in China is to include modern examples, in touch with international trade of today.

As can be expected, there is opposition to tampering with ideas and pedagogical methods used by some instructors: some are content to follow paths laid out previously, and to keep the definition of business communication narrow. Contrastingly, several scholars now feel that China has an opportunity to apply some of the theoretical underpinnings of traditional business communication to an international context.

To borrow wholesale from American texts is impossible: for Chinese students the examples in U.S. texts are not applicable. Consequently, we have borrowed some U.S. organizational structure and bonded that to the international business scene. ${ }^{2}$

\section{Tentative Structure}

A typescript copy of the project is currently being used at UIBE; it is being reviewed by students, by faculty of the School, and by various ministry committees. The venture is so seminal that the authors spent several days in Beijing meeting with faculty groups, discussing pros and cons, and refining the typescript edition. Currently, the suggested contents for this first work on international business communication follow this format.

\section{Part 1-Communication Theory and Application of the Theory}

In 1983 the following statement appeared: "An absence of theoretical underpinning (in the old textbook Business Correspondence) is noticeable. The old adage of practice precedes theory may be operating here, but at the moment there is a prominent lack of concepts as to what occurs between sender and receiver, and a host of other problems which intervene in the communication process." 3 
Communication in foreign trade, an inseparable part of business communication, is a science, a discipline of learning. A textbook to be used in a university must undergird its pragmatic side. Unfortunately, the Chinese do not have a homemade theory to underpin the course. So we turn to the West to find communication theory in countless business communication textbooks. Those books, however, primarily discuss domestic and not international business. And for domestic business in China only the Chinese language is used.

English is an international language. Almost nine out of ten business letters Chinese business sends abroad are written in English. This new textbook will therefore be in English.

One cannot copy the American concepts of business communication mechanically; rather they must be adapted to the Chinese environment. Thus, the first part of the book includes the following chapters:

\section{Chapter 1. Basic Concepts}

In this chapter the intent is to explain what occurs (verbal and nonverbal) between the sender and the receiver, noting such topics as informational theory, theory of human communication, communication models, and a deductively arrived at definition of communication in foreign trade: "Communication in foreign trade is a process by which an oral or written message is exchanged between individuals of different cultures through a common system of symbols, signs or behavior, with a view at producing actual effects in foreign trade."

Chapter 2. Communication Problems Between Businesspeople of Different Cultures

The intent here is to emphasize cross-cultural communication problems, especially between Chinese and English-speaking businesspersons. Examples are taken from written communication, oral, nonverbal, and situational perspectives, as seen from both sides. Headings include cross-cultural communication models; a commonality analysis of overlapping similarities and differences; and a review of "roots of communication difficulty" as seen in different social systems, China's cultural tradition, cultural inheritance, and the position of language in culture.

A brief section is also devoted to oral and written styles, as they differ cross-culturally.

Chapter 3. Business Writing Principles (I)

Chapter 4. Business Writing Principles (II)

American business communication teachers would feel proud to recognize that several of their writing principles are echoed here: completeness, conciseness, consideration, concreteness, clarity, courtesy, and correctness.
Whether writing for international business or for local idea transmission, we feel the principles should be similar.

Comparative examples give force to the argument that not all cultures communicate the same-hence, included are illustrations of British/American and Chinese/ American writing styles.

The basis for the above generalization is captured in a brief quotation from the trial text: "No two cultures have the same knowledge of words, nor do any two cultures give the same meanings to all the words held in common, especially in international trade. The differences are great and present major problems in business communication between different cultures. ${ }^{-5}$

\section{Part 2-Business Correspondence in English}

Today's Chinese students in international business will be tomorrow's international businesspersons. They must know how to communicate effectively in English with foreigners. Of the international communication methods available in China, letters and telex messages are the most important. Thus, the contents of Part 2 are organized according to the export communication topics and problems most commonly faced.

Communication in foreign trade as a course can only be offered to the seniors at UIBE, because three prerequisites demand student ability in the following areas:

- First, students must have a good command of the English language, oral and written.

- Second, they must have a good foundation in basic principles and procedures of international business: international finance, accounting, and economics.

- Third, the students must be competent in related sciences, such as history of the world and world geography.

Chinese students will face varied cross-cultural communication issues; they must be exposed to the custom, habits, and way of life of foreign countries, especially of the English-speaking world.

Compared with the previous textbook, our current emphasis suggests how to write more effectively, while the old stresses how to translate correctly.

In Part 2 we suggest that students may write more informally instead of in trite and formal language, more reminiscent of the early $1900 \mathrm{~s}$; but we do not advocate the idea that Chinese should write as they speak. There are obvious differences in sentence structure between written and oral messages, as well as in the choice of words and expressions. If a student writes in a business letter the sentence, "I'll be damned if I know," the reader would feel the casual remark is out of place.

Since not all managers in Chinese import and export corporations can speak and read English, translation from 
Chinese into English and vice-versa is, therefore, still required of their junior officials. Students-who could move into those junior positions-are expected to be good translators, and they must be prepared for this work.

Indeed, to much of the world English is a foreign language. We may say that the business world speaks English, but that is more true of the younger generation in foreign countries. Senior officials, senior businesspersons in China-often the ones who will make significant decisions-may know little English, or none. Hence, translation exercises are numerous in Part 2 of the text.

Readers will quickly conclude that international business communication, as envisaged in our tentative text, focuses not only on the traditional precepts of good writing, but on translating those principles into one's second language as well. Or, in reverse, a Chinese businessperson must translate into Chinese the substance of the English message. That task is not easy. Note the following stilted student example:

We have received your letter of June 10,1985 and we thank you for it. We welcome you to come to the Guangzhou Export Commodities Fair. Though it is a little late, but please rest assured that we will do our best to send you an invitation card to the fair.

While the message is comprehensible, critics would call it wooden, simplistic, even trite. Thus, translation-good English into Chinese-demands Chinese competence in and an understanding of the English business idioms which students in the U.S., as well as their instructors, take for granted. Not only do Chinese business students have to know the English business equivalents, they must know the Chinese equivalent, certainly adding to the problems of international business communication.

Chapter titles for Part 2 follow.

\section{Chapter 5. Business Letters: Style and Format}

Basic discussion of placement on a page, appearance of the document, and formats.

\section{Chapter 6. Standard Parts of the Letter}

Again, suggestions to students parallel traditional U.S. business communication texts, including such topics as headings, inside address, salutations, body of the letter. and complimentary close.

\section{Chapter 7. Telexes}

Because China-in most areas of business-lacks extensive electronic capabilities, we currently stress the telex as the dominant form of communication. Here a third dimension or problem occurs (English to Chinese and Chinese to English were initial problems); namely, abbreviations. In fact, even American students would slowly go through the following example:

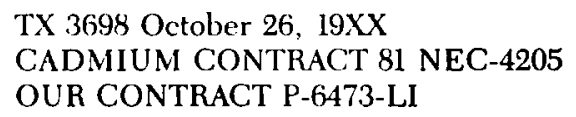

TH YU FOR TELEX 24 OCTOBER REFERENCE REGF. MI0/880 AND WOULD PROPOSE IF SHIPMENT OF 100 TONS MIN 99.99 PCT. CD STICKS IS MADE IN DECEMBER 19XX WE CHANGE PRIMARY FORMULA TO A MIN OF THE PRICE IN LONDON METAL BULLETIN, EUROPEAN FREE MARKET FOR CADMIUM STICKS IN WAREHOISES IN DOLLARS PER POUND FOR NOVEMBER, AL/C 45 DAYS AFTER B/L DATE.

\section{WE LOOK FORWARD TO YOUR RESPONSE.}

\section{REGARDS, ${ }^{6}$}

Visualize a Chinese student translating the above statement into Chinese, in addition to wrestling with an inconsistent use of abbreviations between companies.

\section{Chapter 8. Inquiries and Replies}

Two categories of information are discussed: general inquiries (writer asking general information of a company) and business inquiries (writer requesting detailed information about prices, products, even a possible quotation). The discussion is not dissimilar from that in U.S. business communication texts.

\section{Chapter 9. Quotations and Offers}

A quotation is a response to an inquiry and on an international scale may include prices; discounts in terms of payment; what prices cover, such as packing, freight, insurance, delivery date, and valid period of the quotation. Often Chinese quotations are quoted subject to confirmation; that is, a company may send the same (quotation to other buyers, waiting for the most favorable terms.

Numerous Chinese to English and English to Chinese examples of quotations/counter-quotations conclude this section of the work.

Executing an order demands grasping international business terms such as banker's transfer, bill of exchange, trade bills, drafts, or letters of credit. Additionally, Chinese students learn how to translate and use terms involving international insurance and shipping, as well as claims and settlements.

Some may feel the above procedure would, over time, be routine. Well, it may. Yet, to students who only recently saw a shift from a primarily agrarian economy to a world economy, the linguistic and business communication problems are formidable. 


\section{Part 3-Representative Case Studies}

This part replicates what is characteristic of some American texts: inclusion of actual cases on a problem. Three cases are included:

- Case 1. A Chronology of Events on Importing Medical Instruments from the U.S.A. through a Hong Kong company.

- Case 2. A Joint Venture Between a Chinese Company and a Company in West Germany.

- Case 3. A Claim on a Shipment from Canada.

All three cases are closely related to new developments in China's economic and trade relations with foreign countries. It is important to let students learn what happens between international buyers and sellers and the kinds of communication exchange between them. Students read the actual documents of a real case, even read a telephone conversation, as career preparation.

\section{CONCLUDing Remarks}

As China moves toward modernization. the current Chinese business communication textbook is also undergoing fundamental changes. The progress may appear glacially slow to some Americans-yet there is movement.
Our goal is a Chinese business-communication textbook limited to and defined as communication in foreign trade, aimed at eliminating trite expressions, outof-date style and format in the business writing of Chinese engaged in international business. Some Chinese say that a message is good as long as it can bring about the expected results, no matter whether the writer has used up-to-date expressions or not.

In an earlier article a challenge to American business communicators was issued:

Opportunities at an early stage are available to us in the U.S. to help those business schools in China which have business communication as a core requirement. This means sharing ideas, providing examples, clarifying intercultural differences, arranging exchange visits-all to improve relationships between our nations and to foster business communication as a truly international discipline. ${ }^{7}$

Thus this statement is a progress report on that challenge, and suggests a wider concept of business communication for a country where good communication and foreign trade are central to its progress. If business students on both sides of the Pacific share the same ideas on how to communicate effectively with foreign businesspeople, the trade volume and the communication related to it-particularly between China and the United States-will surely improve.

In some measure that is what our project is about.

NOTES

1. Business Correspondence, (1979). Beijing

2. Specific texts depended on included: Lesikar, R. Business Communication (5th ed.), (Homewood, IL: Richard D. Irwin, Inc., 1984); Murphy, H. and H. W. Hildebrandt. Effective Business Communications (4th ed.), (New York: Mc.Graw Hill, 1984: Sigband, N. Communication for Management and Business (3rd ed.), (Glenview, IL: Scott, Foresman and Company, 1982).

3. Zong, B. and H. W. Hildebrandt. "Business Commu- nication in the People's Republic of China," The Journal of Business Communication. Vol. 20. No. 1, Winter 1983, pp. 25-32.

4. Zong, B., Y. Shammin, and H. W. Hildebrandt. Communication in Forcign Trade (in typescript), (Beijing: University of International Business and Economics, 1985), p. 11.

5. lbid., p. 37.

6. Ibid., p. 27.

7. Op. cit., Zong and Hildebrandt.

\section{DIRECTORY ADDITIONS}

On the pages of the March 1986 Bulletin where the committees are listed, add Richard David Ramsey to both the Committee on International Communication and the Committee on Teaching Methodology and Concepts. 